\title{
水力発電所水圧鉄管内部の無線通信実験について
}

\author{
福 澤 修一朗*

\section{On Wireless-communication Experiment in Penstocks of Hydroelectric Power Stations}

\author{
Shuichiro Fukuzawa*
}

\begin{abstract}
In order to establish a secure communication network during periodic inspection of hydroelectric power stations, the thesis conducts the radio propagation experiment in penstocks. To begin with, using an experimental apparatus which produces multi-path environment of line-of-sight area, transmission characteristics of a wireless LAN are measured. Next, based on the results, a set of antenna system which reduces the communication failure in line-of-sight area is developed. Then, the effectiveness of the system is experimentally confirmed in the straight section of a penstock. Furthermore, the means added to the system in order to solve problems of wireless LAN communication of over-the-horizon area are devised, and the performance of the advanced system is evaluated with an experimental apparatus which produces multi-path environment of over-the-horizon area. Finally, the effectiveness of the proposed system is experimentally verified in whole penstocks including bend.
\end{abstract}

Key Words: Penstock, Wireless LAN, Multi-path Environment, Radio Propagation Characteristics

\section{1.は じめに}

水力発電所水圧鉄管は, 水を高い所から落下させ, 水の位置 エネルギーを発電機の運動エネルギーに変換する主要構造物で ある. 水圧鉄管には高水圧が作用するため, 内外面の塗膜の防 食効果により設計板厚を保持する必要がある。このため, 水圧 鉄管は，適宜，外面・内面とも塗り替え補修を行わなければな らない.

このうち, 水圧鉄管外面は作業員による日常の巡視点検で塗 装状態や発錆状況の把握が可能であるが, 内面は充水状態にあ るため, 定期保安工事で抜水されたときなどの限られた場合にし か, 状況を把握できない. また, 内面の状況把握は, 断水の時間 的制約があり，急勾配箇所を含むなど危険を伴う作業でもある。

当社水力発電設備は建設後数十年を経過したものが多く, 今 後ますます経年化が進むにつれ, 設備健全性をより詳細に把握 するニーズが高まると予想される。 さらに，昨今の電力業界を 取り巻く環境の変化や電力需給の逼迫により, 定期保安工事は できるだけコストを抑え, かつ, 停電期間を短縮することが求 められ，短時間で質の高い状況把握が要求される.

市販センサに目を向けると, 近年, ネットワークカメラなど, 遠隔地から機器を参照・制御できる ICT 技術 (Information and

原 2012 年 12 月 5 日

*北海道電力株式会社

${ }^{*}$ Hokkaido electric power Co., Inc.

ロ 本論文は有用性で評価されました。
Communication Technology）が実用化されている。これらを 水力発電設備の内面点検に活用すると, 安全・低コスト・短時 間で健全性の詳細把握が実現できる，例えば，ネットワークカ メラを用いると, 作業員が水圧鉄管内部に入ることなく, 近接 目視検査が可能になる.

ICT 技術を活用するためには通信網の確保が必要である。し かし, 水が充填される前提の水圧鉄管内部に通信網は設置され ていない. 当社水圧鉄管の約 9 割は延長 400 [m] 以下で, 長い ものは $1,000[\mathrm{~m}]$ 以上に及ぶ. 長距離データ伝送を行うため, い かにして一時的な通信網を確保するかが ICT 技術活用の一つの 課題になる。 また, 一時的な通信網の確保には, 通信ケーブル 方式・無線方式の 2 とおりの方法が考えられる.

ところで, 延長が数百メートルに亘る管状構造物の内面点検 装置には，種々の分野で開発事例がある.

文献 [1] は積水化学工業が開発した下水道管渠内 TVカメラ調 査システムである.ゴム車輪で自走し, $190^{\circ}$ の超広角レンズで 撮影した内径 $\Phi 0.25[\mathrm{~m}]$ の下水道の管内画像を通信ケーブルで データ伝送する。伝送された設備画像は, リアルタイムで展開画 像に変換され TV モニタで確認できる. 文献 [2] は東電工業が開 発した管路・暗きょ内部検査ロボットである. マグネット車輪で 自走し, 内径 $\Phi 0.5[\mathrm{~m}] \sim \Phi 4.5[\mathrm{~m}]$ の鉄管の管内画像を $250[\mathrm{~m}]$ のアナログケーブルでデータ伝送する. 最近では, 鋼管肉厚・塗 膜厚さを測定でき, データ伝送距離も500 [m] に長距離化した 模様である [3]. 文献 [4] は大阪ガスが開発したガス導管検査口 ボットである. 独自の二重磁石車輪で自走し, 内径 $\Phi 0.15[\mathrm{~m}] \sim$ 
$\Phi 0.6[\mathrm{~m}]$ の鉄管の異径管接続部の段差・ $\mathrm{L}$ 字管・ $\mathrm{T}$ 字管を移動で き, 光ファイバケーブルで溶接線などの設備画像を長距離デー 夕伝送する, 文献 [5] [6] は北海道立工業試験場（現在, 北海道 立総合研究機構）の指導のもと, 川崎建設が開発した畑の排水 用地下埋設管の検査・洗浄装置である. 先端部はカメラ・方向 制御機構・洗浄推進用噴射ノズルを備え, 内径 $\Phi 0.05[\mathrm{~m}]$ の分 岐管数百メートルを検査・洗浄できる，画像情報は通信ケーブ ルで長距離デー夕伝送する。

文献 [7] は当社が開発した水圧鉄管内面点検装置である.内径 $\Phi 3.5[\mathrm{~m}]$ 程度の鉄管の管内画像と塗膜厚さデータを最長 $400[\mathrm{~m}]$ の通信ケーブルでデー夕伝送する，主な特徴は，水圧鉄管が勾 配を持つことに着目し自重移動方式を採用したこと，装置を人 肩で運搬できるまで簡素化・軽量化したこと, 内蔵バッテリの みでデー夕取得できる（電源ケーブル不要）などである.

いずれの開発事例も，管内画像などの測定情報の長距離デー 夕伝送には, 無線通信ではなく, 点検装置と一緒に挿入する通 信ケーブルを用いる，通信ケーブルを用いる理由として，ガス 導管などの小径管は， $\mathrm{T}$ 字管などにおける無線通信の減衰が大 きいため, 長距離での適用が難しいことがあげられる. また, 水 圧鉄管などの中径〜大径管は，無線通信を用いると管路内でマ ルチパスによる通信不具合が想定されるため, 安定的にデータ を取得できる通信ケーブルが選択されたと考えられる。

当社装置 [7]は，2010 年度から実運用に入り，水圧鉄管内面 塗装工事の繰延べ等のコストダウンに寄与しているが, 点検に 要する人員は，（1）キャプスタン（電動ウィンチ）操作，（2） 管内画像取得・塗膜厚さ測定・距離計測, (3) 通信ケーブルの 送出・巻取の, 3 人工である. 送り出した最長 $400[\mathrm{~m}]$ に及ぶ 通信ケーブルを現地で巻き取る作業も，容易ではない，長距離 デー夕伝送を無線通信化できれば，1 人工減と巻取作業の解消 で，検査期間・検査費用を低減することができる。

なお，金属配管内を無線操作で検査するロボットの開発事例 として, 群馬大学の吉野らによる配管内検査ロボットがある [8]. 論文では鉛直 $\mathrm{T}$ 字管を有する配管網内を自在に移動する磁気 吸着クローラ設計法を提案し, 提案方法に基づいて無線操作式 磁気吸着配管内検査ロボットを開発し, 配管網内走行実験によ り有効性を実証している．ただし，無線周波数が $45[\mathrm{MHz}]$ や $57[\mathrm{MHz}]$ と低いこと, 無線通信を確立するため配管内部各所へ のアンテナ配置を前提とすることから，このまま延長数百メー トルの水圧鉄管内面点検に適用することは難しいと思われる.

一方，トンネル・地下街などの閉所狭隘空間で無線通信を行う と, 通信不具合を生じやすいことが知られており, これらを無 線の不感地带という。不感地带における無線伝搬特性の実験的 研究や無線通信システムの開発事例には, 鉄道トンネル・導水路 トンネル・地下トンネルなどを対象にした研究がある [9]〜 [12].

文献 [9] は当時, 陸上移動通信として将来マイクロ波帯が使 用されることを予想し，JR トンネル（等価半径 $4.2[\mathrm{~m}]$ また は $4.5[\mathrm{~m}]$ ）におけるマイクロ波帯の無線伝搬特性を理論・実験 の両面から検討した研究報告である. 報告では, 無線周波数が $800[\mathrm{MHz}]$ 以上になると高次モードが伝搬する多重モード伝搬 になること, 直線区間は周波数が高くなると減衰定数が小さく なるが, 曲線区間は逆に減衰定数が大きくなること, アンテナ
位置を適切に配置すれば（適当な電波励振を行えば）電波到達 距離を伸ばせる場合があることを示している。

文献 [10] は導水路トンネルなどの小口径トンネルを対象にし て, 文献 [9] よりも広範囲なマイクロ波带の無線伝搬特性を実験 的に調べた論文である。論文では，等価半径 $0.8[\mathrm{~m}] \sim 4.55[\mathrm{~m}]$ のトンネルに打ける, 無線周波数 $200[\mathrm{MHz}] \sim 50[\mathrm{GHz}]$ の減衰 定数を高い精度で計算できる実験式が提案されている。

文献 [11] は首都圈地下数十メートルに建設された洪水一時 貯水・放水用シールドトンネル内部を, 無人飛行船に搭載した カメラで撮影し, $2.4[\mathrm{GHz}]$ スペクトラム拡散方式の無線 LAN で地上基地局にデータ伝送するシステムの開発事例である。論 文では，ローミング機能付き固定局を複数設置し，アンテナ・ ダイバーシチを構成し, 結合損失が小さくなるようアンテナ位 置を工夫した結果，マルチパス環境下で見通し外通信となる約 $2,000[\mathrm{~m}]$ 区間のリアルタイムデータ伝送に成功している.

文献 [12] はトンネル断面の小さい導水路トンネル築造工事に おいて, 遠隔設置されたコンクリートポンプのオペレータがコ ンクリート打設箇所の作業員を目視確認し, 音声で相互通信で きるようにした，画像無線伝送システムの開発事例である。論文 では, $2.4[\mathrm{GHz}]$ スペクトラム拡散方式の無線 LAN で $550[\mathrm{~m}]$, $50[\mathrm{GHz}]$ 带簡易無線で $700[\mathrm{~m}]$ のデー夕伝送が可能なことを報 告している.

また，閉所狭隆空間で無線 LAN が通信不具合を生ずる別の 要因として, 同一信号の電波が異なる経路を通過し時間差を伴 う複数の電波として受信機に到達することにより（マルチパス）, 符号間干渉誤りを発生することが考えられる。この誤りの発生 量を統計的に評価する指標として, ビット誤り率（BER）が用 いられる [13].

文献 [14] は, 屋内伝搬環境を例にして, 等価伝送路モデルを 用いて BER マップを作成する手法を提案した論文である，屋 内伝搬環境はモデル化しやすいため, レイトレーシングによる 解析 [15] が主流であるが, BER マップを作成するには計算量 が膨大になるという問題がある，等価伝送路モデルは，適当な パラメータとフェージングモデルを用いてマルチパスを 2 波モ デルに等価したもので，これを用いると十分な近似精度でBER マップを簡易計算することができる.

さらに，金属配管を導波管と見なし，電磁波伝搬実験と解析 を行った研究もある [16]. 論文では金属配管中に遮断周波数よ り数\%高い周波数の電磁波を伝搬させ, 測定器で計測した伝達 関数の形状から配管異常（形状変形）を検知する手法を検討し ている，そして，配管経路や変形箇所に関係なく変形の仕方が 同じであれば伝達関数の変化も同じである, 矩形配管および円 形配管とも遮断波長に寄与する方向の変形については異常検知 が可能であるなどの知見が得られ, 実験值と FDTD 法 (Finite Difference Time Domain Method）の解析結果も良好に一致 している.

ただし，文献 [9]〜 [12] は，壁面がコンクリートのトンネルに 関する検討結果である．本論文の対象とする水圧鉄管と異なる 点は, トンネルはコンクリートの誘電率が伝搬特性に大きく影 響するが, 水圧鉄管の場合は, 壁面が導体なので導電率のみが 伝搬特性に影響し, 電波の減衰が小さいことである。 また, 文 
献 [14] [15] は無線 LAN の屋内伝搬環境・携帯電話の移動体通 信を想定したものである.さらに，文献 [16] は基本モードのみ 伝搬する小口径配管を対象にしているため，水圧鉄管のような 高次モードが混在する環境でその知見を活用するには検討が必 要と思われる.

以上の背景のもと, 定期保安工事における一時的な通信網の 確保を可能にする無線通信システムを検討するため, 水力発電 所水圧鉄管内部の無線通信実験を行うことにした。通常の水圧 鉄管は直線部のほか, 設置環境に応じて勾配変化点などのベン ドがある，そこで本研究では，水圧鉄管直線部とベンドを含む水 圧鉄管の二つの場合に分けて，無線通信システムの検討を行う.

これまでに，マルチパス環境を人工的に作り出す屋内実験装 置を用いて無線伝搬特性を調へ，水圧鉄管直線部の通信不具合 を解消する方法を考案し, 実機水圧鉄管直線部でその効果を確 認した（見通し内通信実験）[17]. 次に, ベンドにおける通信不 具合を解消できる可能性の高い方法を選択し, 直線部の通信不 具合の解消方法と組み合わせることにより, ベンドを含む実機 水圧鉄管で良好な性能試験結果を得た（見通し外通信実験），以 下にその内容を報告する．

\section{2. 使用する無線通信器材ほか}

\section{1 見通し内通信実験}

屋内実験装置による無線伝搬特性測定（1）および実機水圧鉄 管による無線通信実験（1）では, $2.4[\mathrm{GHz}]$ 帯無線 LAN ルータ (IEEE802.11b 規格, アライドテレシス製 Centre COM WR54ID）を用いる. 無線 LAN ルータの設定条件を Table 1 に示す.

また，通信不具合を生じにくい送受信アンテナを提案するた め, 不要な回り込み電波をカットできるように矩形筐体の両端 を閉塞する形で, $2.4[\mathrm{GHz}]$ 帯パターン電波吸収体（ニッタ製 PFN10-2.4G-3.3-500×500）を用いる。この電波吸収体は, 電 波受信側から順に, パターン層, 吸収体層, 誘電体層, 反射層 の多層構造になっており, パターン層で捉えた $2.4[\mathrm{GHz}]$ 帯の 電波を効率よく吸収できる仕組みになっている.

\section{2 見通し外通信実験}

屋内実験装置による無線伝搬特性測定 (2) および実機水圧鉄管 による無線通信実験（2）では，無線 LAN ルータ（IEEE802.11n 規格， NEC 製 Aterm WR9500N）を用いる。本ルータは, $2.4[\mathrm{GHz}]$ 帯と $5[\mathrm{GHz}]$ 帯のいずれかを選択できるが, 見通し内

Table 1 Specification of wireless LAN (1)

\begin{tabular}{|c|l|}
\hline Protocol & IEEE $802.11 \mathrm{~b}$ \\
\hline Radio frequency & $2.4 \mathrm{GHz}$ (Center frequency $2.412 \mathrm{GHz})$ \\
\hline Bandwidth & $20 \mathrm{MHz}$ \\
\hline Modulation & Direct sequence spread spectrum (DSSS) \\
\hline Data rate & $1 / 2 / 5.5 / 11 \mathrm{Mbps}$ \\
\hline MIMO & None \\
\hline
\end{tabular}

Table 2 Specification of wireless LAN (2)

\begin{tabular}{|c|l|}
\hline Protocol & IEEE802.11n \\
\hline Radio frequency & $2.4 \mathrm{GHz}(2 \mathrm{CH}: 2.417 \mathrm{GHz}$ and $2.437 \mathrm{GHz})$ \\
\hline Bandwidth & $20 \mathrm{MHz}$ \\
\hline Modulation & $\begin{array}{l}\text { Orthogonal frequency division multiplexing } \\
\text { (OFDM) }\end{array}$ \\
\hline Data rate & Maximum 300 Mbps \\
\hline MIMO & 2 streams (Transmitting 2, Receiving 2) \\
\hline
\end{tabular}

通信実験の結果と対比させるため, $2.4[\mathrm{GHz}]$ 帯を選択する. 無 線 LAN ルータの設定条件を Table 2 に示す。なお, 表中の MIMO は Multiple input multiple output の略で, 送信アン テナと受信アンテナを多重化することにより, 伝送速度を増加 させる技術である．

また，直線部の通信不具合を解消するため，引き続き $2.4[\mathrm{GHz}]$ 帯パターン電波吸収体（ニッ夕製 PFN10-2.4G-3.3-500×500） を用い, 性能比較実験として Table 1 の無線 LAN ルータも用 いる.

\section{3. 屋内実験装置による無線伝搬特性測定（1）}

\section{1 屋内実験装置（1）}

マルチパス環境を人工的に作り出すため, 内部に送受信アン テナを設置したアルミ製矩形筐体（縦 $0.40 \times$ 横 $0.40 \times$ 長さ $3.60[\mathrm{~m}]$ ）を製作した。送受信方向端面（両端）は，アルミ板で 閉塞, 電波吸収体で閉塞, 開放の 3 ケースを選択できる。送受 信距離は, 外部から受信アンテナ位置を操作することにより任 意に設定できる。製作した筐体を Fig. 1 に示す.

測定内容は，（1）送受信距離に対する受信電力の変化，（2） 無線周波数に対する筐体内部の損失と位相の変化, (3) 送受信 距離に対するスループットの変化である. 無線伝搬特性測定の 装置接続図を, Fig. 2 に示す. 測定（1）は端子 a-c と b-d を接

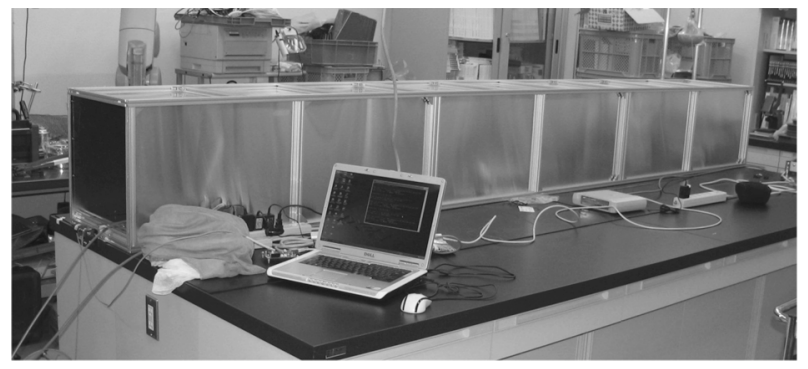

Fig. 1 Indoor experimental apparatus for producing a multipath environment of line-of-sight area

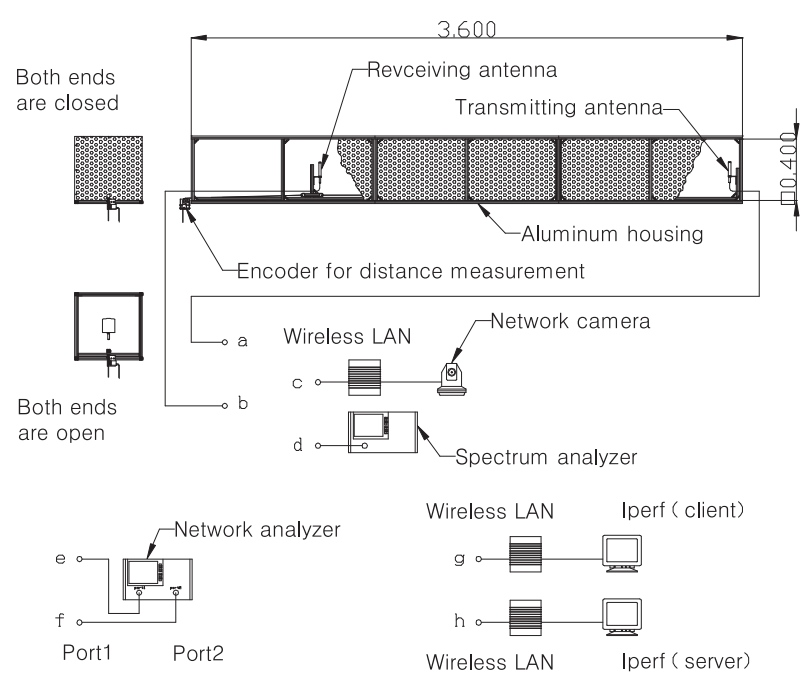

Fig. 2 Connection diagram of devices for measuring the radio propagation characteristics 


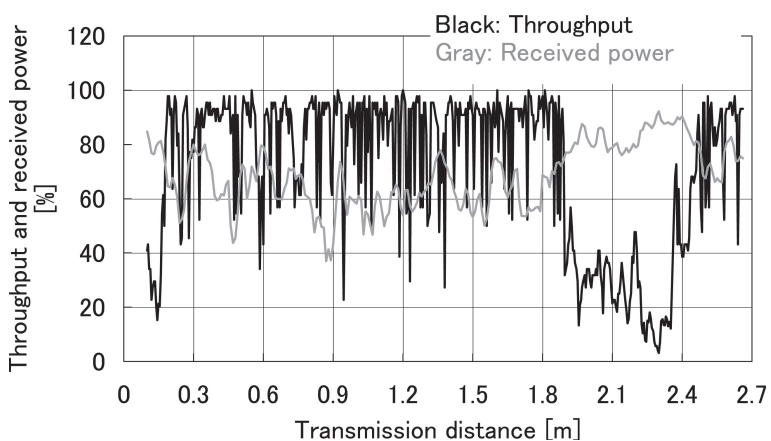

Fig. 3 Throughput and receiving power (Both ends are closed by aluminum plates)

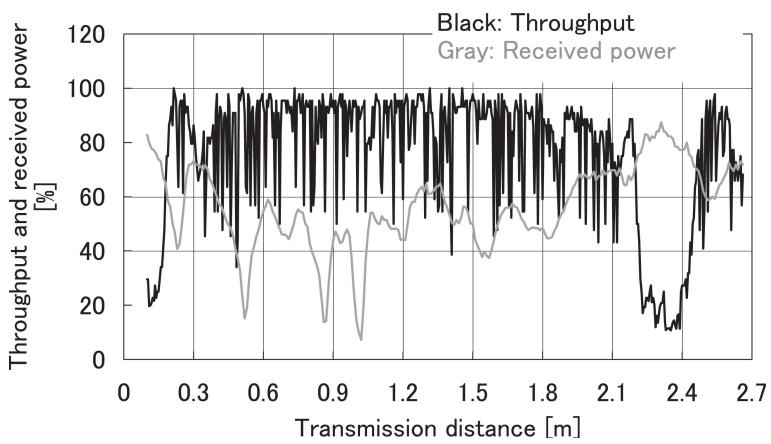

Fig. 4 Throughput and receiving power (Both ends are closed by microwave absorbers)

続，測定（2）は端子 a-e と b-f を接続，測定（3）は端子 a-g と b-h を接続して行う. 図のスペクトラムアナライザは無線 LAN ルータの出力信号の電力レベルと周波数を測定する装置, ネッ トワークアナライザは送信アンテナ入力端子から受信アンテナ 出力端子までの伝送損失と位相遅れを測定する装置である。ま た, Iperf は, 米国が開発したスループット測定用オープンソー スソフトウェアである [18].

\section{2 測定結果}

アルミ板で両端を閉塞した場合の，送受信距離に対するスルー プット（黒）と受信電力（灰）の変化を, Fig. 3 に示す. スルー プットは送受信距離 $1.90[\mathrm{~m}] \sim 2.50[\mathrm{~m}]$ の区間で低下し，受信 電力はその区間で増加することが分かる.

電波吸収体で両端閉塞した場合の，送受信距離に対するスルー プット（黒）と受信電力（灰）の変化を Fig. 4 に示す. Fig. 3 と比ベてスループットの低下は送受信距離 $2.20[\mathrm{~m}] \sim 2.50[\mathrm{~m}]$ の区間に減少しており, 電波吸収体により通信不具合が軽減さ れることが分かる，ただし，スループット低下区間では，Fig. 3 と同様に受信電力が増加する. なお, Fig. 3 と Fig. 4 のスルー プットの縦軸単位は $0 \sim 4.4[\mathrm{Mbps}]$ を $0 \sim 100 \%$ としたもの, 受 信電力は $-30 \sim 0[\mathrm{dBm}]$ を 0 100\%としたものである.

Fig. 5 は，送受信距離 $1.60[\mathrm{~m}]$ に打ける筐体内部の損失と位 相を逆フーリエ変換し, 送受信アンテナ間の遅延プロファイル を求めたものである。黑は電波吸収体で両端閉塞，灰はアルミ 板で両端閉塞した場合である。遅延プロファイルは, 時刻 0 に 送信アンテナが送信したインパルスを，受信アンテナが受信す る様子を表す。また, 縦軸単位は遅延プロファイルのピーク值

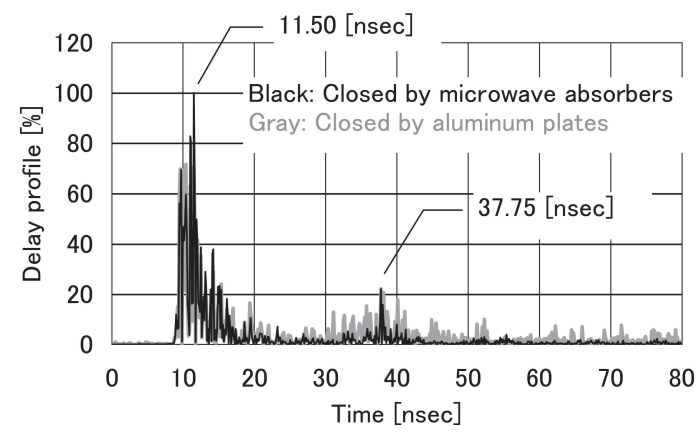

Fig. 5 Comparison of two delay profiles

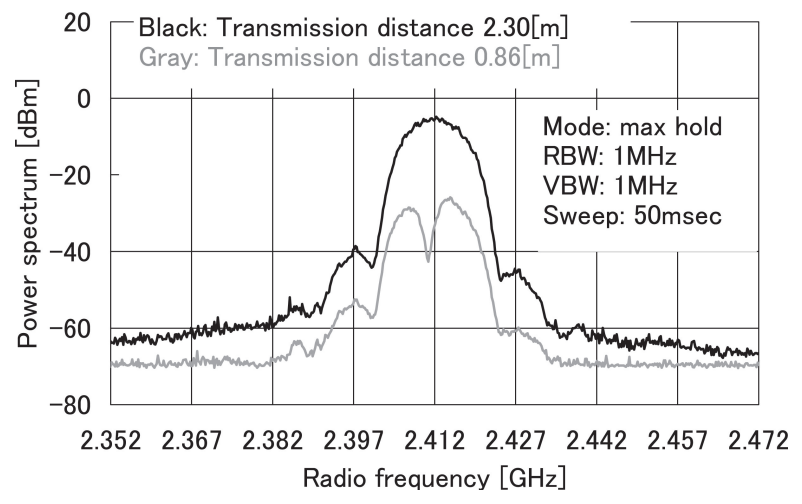

Fig. 6 Power spectrum of the received signal

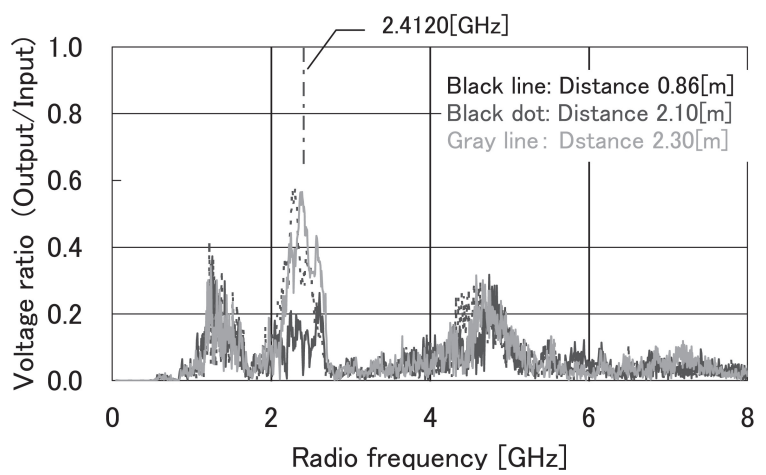

Fig. 7 Voltage ratio of a receiving antenna output to a transmitting antenna input

165.3 を 100\%に換算している. 図の最初のピーク（11.50[ns]） は直接波, 2 番めのピーク $(37.75[\mathrm{~ns}])$ は送受信方向の 1 回反 射波である。図より, 長い軸を持つ構造物内部では, この軸方 向に遅延プロファイルが広がることが分かる。また，黒と灰を 比較すると, 反射波前後の黒のノイズが軽減している。これは, 電波吸収体によって，送受信方向の反射波が吸収されるためと 推察される.

スループット低下部（黒: 送受信距離 $2.30[\mathrm{~m}]$ ) と, 良好な箇所 （灰：送受信距離 $0.86[\mathrm{~m}]$ ）における電力スペクトルを, Fig. 6 に示す，電力スペクトルは，電波吸収体で両端を閉塞して測定し たものである。このうち, 灰は中心周波数が大きく歪みフェージ ングを生ずるが, 黒に歪みはなく受信電力が全体的に増大する。

Fig. 7 は，ネットワークアナライザの損失測定結果から求め 
た送受信アンテナの入出力電圧比 (受信アンテナからの出力電圧 ：送信アンテナへの入力電圧）である. また, 損失は電波吸収体 で両端を閉塞して測定したものである. 図の黒線はアンテナ送 受信距離 $0.86[\mathrm{~m}]$, 黒点は $2.10[\mathrm{~m}]$, 灰線は $2.30[\mathrm{~m}]$ の場合で ある. 図より，スループットが良好な $0.86[\mathrm{~m}]$ では無線中心周 波数 $2.4120[\mathrm{GHz}]$ 付近の電圧入出力比は大きくなく, $2.10[\mathrm{~m}]$ では電圧入出力比は大きくなるもののピークが $2.4120[\mathrm{GHz}]$ か ら外れており，スループットが低下する $2.30[\mathrm{~m}]$ ではピークが $2.4120[\mathrm{GHz}]$ に一致することが分かる.

Fig. 3, Fig. 4のスループット低下区間で受信電力が増加する ことや, Fig. 6, Fig. 7 の結果より, 送受信距離 $2.30[\mathrm{~m}]$ に扔け るスループット低下の原因は, フェージングによるものではな く, 矩形笚体が無線中心周波数 $2.412[\mathrm{GHz}]$ で共振（共鳴）す るためと推察される。

\section{4. 通信不具合を軽減させるアンテナの考案}

Fig. 3〜Fig. 5 の検討により, ニッタ製 $2.4[\mathrm{GHz}]$ 帯パターン 電波吸収体には，送受信方向の反射波を吸収し， $2.4[\mathrm{GHz}]$ 帯長 距離無線 LAN ルータのスループットを改善する効果があるこ とが分かった，この知見を活用して，水圧鉄管内部の通信不具

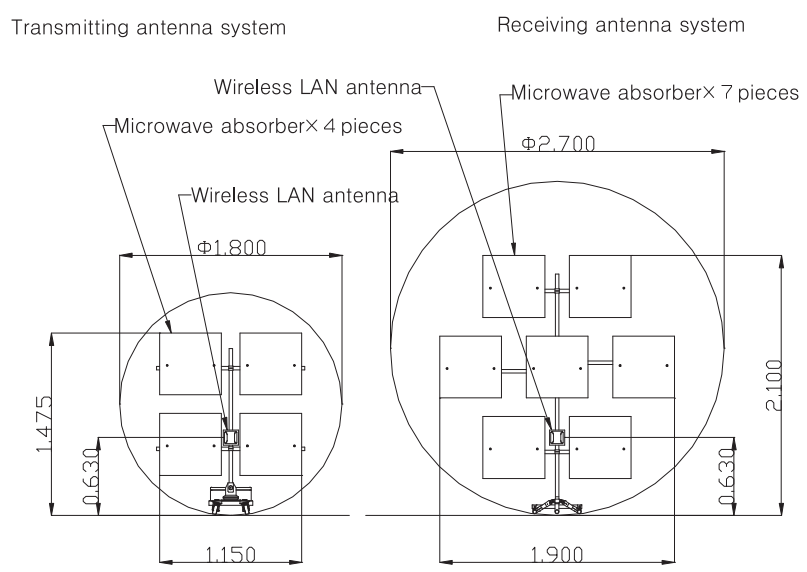

Fig. 8 Conceptual design of the antenna system to reduce the wireless communication failure in a multi-path environment

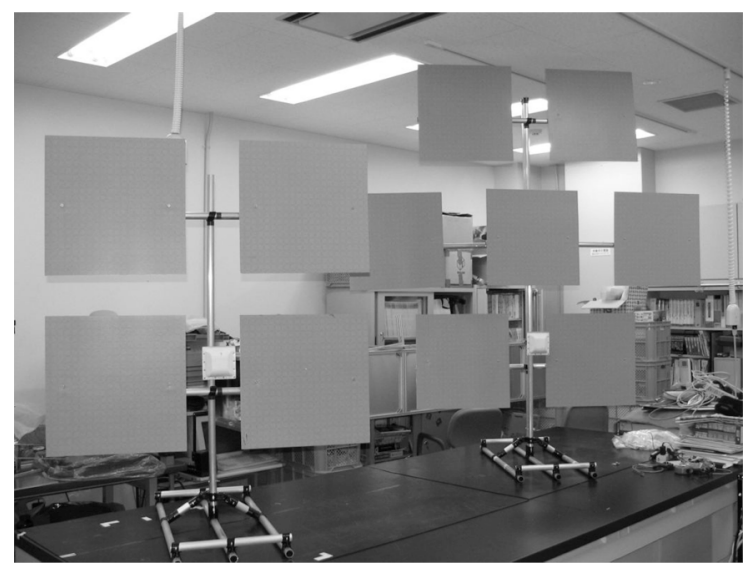

Fig. 9 Developed antenna system (Transmitting and receiving antennas with microwave absorbers)
合を軽減させるアンテナを考案した。

考案したアンテナを Fig. 8 に示す. 図左は, 水圧鉄管内を移 動する点検装置に設置し, 撮影画像や測定デー夕を送信する送 信アンテナ, 図右は基地局に固定し, 点検装置が取得した撮影 画像や測定デー夕を受信する受信アンテナである.

送信アンテナは内径 $\Phi 1.8[\mathrm{~m}]$ の水圧鉄管断面を覆うように電 波吸収体を展開し, 受信アンテナは内径 $\Phi 2.7[\mathrm{~m}]$ の水圧鉄管断 面を覆うように電波吸収体を展開する。展開した電波吸収体で 送受信方向の反射波を吸収し，マルチパスによる通信不具合の 軽減を目指したのが，本アンテナの考案ポイントである.

Fig. 8 の設計図に基づいて製作した送受信アンテナを，Fig. 9 に示す. 送信アンテナの総重量は $7[\mathrm{~kg}]$, 受信アンテナの総重量 は $17[\mathrm{~kg}]$ である. また, 各アンテナをパーツに分解すると, 水 圧鉄管の内部点検用マンホール（長軸 $0.45[\mathrm{~m}] \times$ 短軸 $0.35[\mathrm{~m}]$ の楕円形状）から搬入出可能である.

\section{5． 実機水圧鉄管による無線通信実験（1）}

\section{1 使用水圧鉄管}

使用水圧鉄管は, 2011 年度の当社水力発電所の停電作業計画 および停電作業期間, 水圧鉄管の寸法形状を考慮して, $\mathrm{K}$ 発電 所水圧鉄管を選定した. $\mathrm{K}$ 発電所は, 当社が管理するダム水路 式発電所で, 出力 $25,000[\mathrm{~kW}]$, 水圧鉄管条数 1 条, 水圧鉄管 内径 $\Phi 4.0[\mathrm{~m}] \sim \Phi 3.0[\mathrm{~m}]$, 水圧鉄管延長 $263[\mathrm{~m}]$ である.

$\mathrm{K}$ 発電所水圧鉄管の縦断面図を Fig. 10 に示す. $\mathrm{K}$ 発電所水 圧鉄管はすべて地中に埋設されており，内部に出入りできるの は, 空気弁室（Fig.10内の Air valve room）下の内部点検用マ ンホールだけである。また, 空気弁室から水圧鉄管始点までの 内径 $\Phi 4.0 \times 191.8[\mathrm{~m}]$ は水平部, 空気并室から水圧鉄管終点ま での内径 $\Phi 4.0 \sim \Phi 3.0 \times 71.5[\mathrm{~m}]$ は傾斜部（勾配 $43^{\circ}$ ）である.

無線通信実験中（停電作業期間中）は，水圧鉄管始点のバイ パス付制水門と水圧鉄管終点の入口弁は閉じられ，水圧鉄管内 部は両端が鉄製扉で閉塞された閉鎖空間になる。

\section{2 実験方法}

実験機材の構成と配置を Fig. 11 に示す.まず，受信アンテ ナを空気弁室下の内部点検用マンホール付近（基地局）に固定 し, 図左の水平部と図右の傾斜部の 2 区間について, 電動ウィ

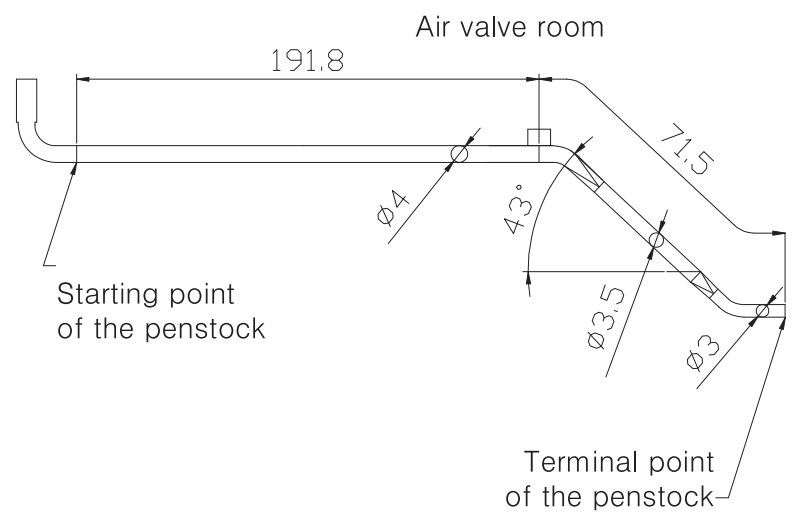

Fig. 10 Longitudinal section of the penstock of "K" hydroelectric power station 


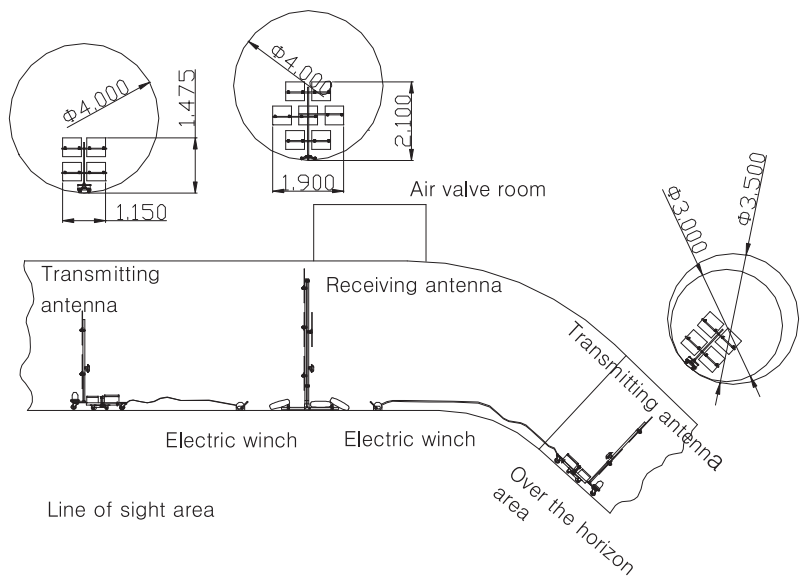

Fig. 11 Device configuration and arrangement of the wirelesscommunications experiment (1)

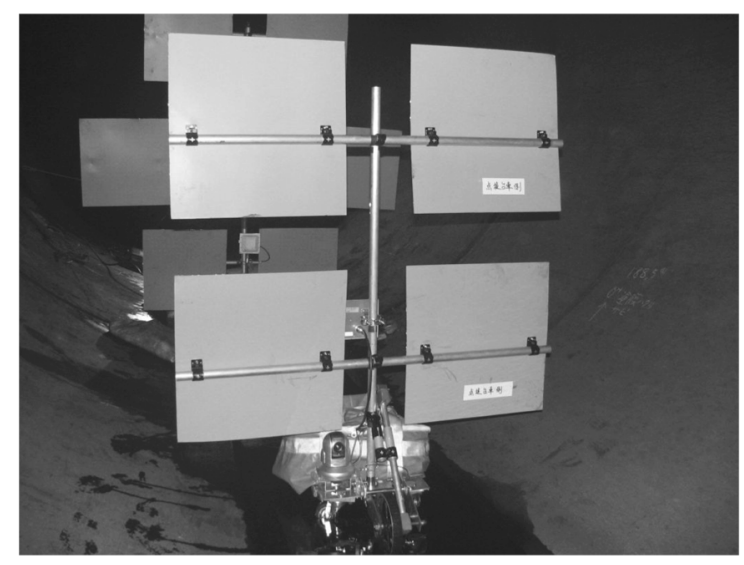

Fig. 12 Experimental scene in the penstock by the apparatus equipped with a transmitting antenna

ンチで送信アンテナを移動させながら実施する。このうち, 水 平部は送受信アンテナが互いに見通せる見通し内通信区間，傾 斜部は送受信アンテナ間にベンドを含む見通し外通信区間であ る。また, 測定項目は, 送受信距離に対するスループットの変 化と受信電力の変化である. 性能比較のため, 送受信アンテナ は, 電波吸収体を展開した場合（Fig. 9）と電波吸収体を撤去し た場合の，2 ケースについて行う。電波吸収体を展開した場合 の無線通信実験の様子を Fig. 12 に示す.

\section{3 実験結果}

Fig. 13 は，送受信距離に対するスループットの変化である. 送受信距離は基地局を基点 0 とし, 水平部（見通し内通信区間） をプラス，傾斜部（見通し外通信区間）をマイナスで表す。黒 は, 送受信アンテナに電波吸収体を用いる場合, 灰は電波吸収 体を用いない場合である。図より, 電波吸収体を用いると, 送 受信距離 $50[\mathrm{~m}] \sim 120[\mathrm{~m}]$ の区間でスループットが改善される ことが分かる.

Table 3 は，水圧鉄管の見通し内通信区間と見通し外通信区 間について, 電波吸収体なしの平均スループット, 電波吸収体 ありの平均スループット, 両者の比（あり／なし）を計算した 結果である。表より，見通し内通信区間では，電波吸収体あり

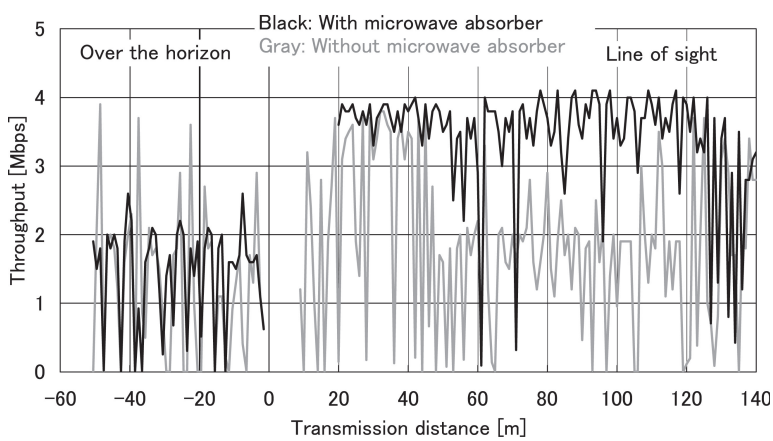

Fig. 13 Change of throughput to transmission distance

Table 3 Comparison of average throughput and its ratio

\begin{tabular}{|c|c|c|c|}
\hline Area & $\begin{array}{c}\text { Without microwave } \\
\text { absorber }(1)\end{array}$ & $\begin{array}{c}\text { With microwave } \\
\text { absorber (2) }\end{array}$ & $\begin{array}{c}\text { Ratio } \\
(2) \div(1)\end{array}$ \\
\hline Line of sight & $1.86[\mathrm{Mbps}]$ & $3.43[\mathrm{Mbps}]$ & 1.85 times \\
\hline $\begin{array}{c}\text { Over the } \\
\text { horizon }\end{array}$ & $1.27[\mathrm{Mbps}]$ & $1.45[\mathrm{Mbps}]$ & 1.14 times \\
\hline
\end{tabular}

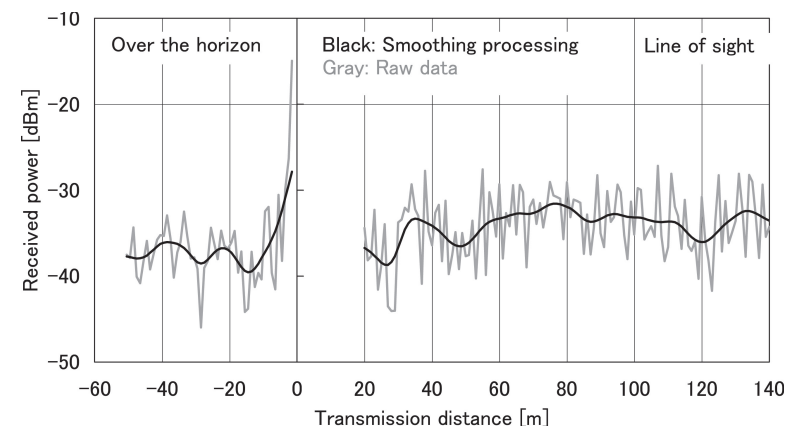

Fig. 14 Change of received power to transmission distance

のスループットが $85 \%$ 向上している（1.85 倍). 現在, 当社が 使用している装置 [7] のスループットは $3[\mathrm{Mbps}]$ なので（通信 ケーブル使用), 無線通信についてもこのレベルを確保したいと 考えている（目標スループット $3[\mathrm{Mbps}])$. 表より, 見通し内空 間で電波吸収体を用いる場合の平均スループットは 3.43 [Mbps] なので，この区間では目標值をクリアしたといえる.

Fig. 14 は，電波吸収体を用いる場合の送受信距離に対する 受信電力の変化（扊）と，その局所荷重平均の計算值（黒）で ある。黒線より, 電波吸収体ありのスループット低下部（送受 信距離 $125[\mathrm{~m}] \sim 140[\mathrm{~m}]$ の区間）では, 受信電力も増加するこ とが分かる。

最後に，スループット低下部（黒：送受信距離 $131[\mathrm{~m}]$ ）と， 良好な箇所（灰：送受信距離 $121[\mathrm{~m}]$ ）における電力スペクトル を，Fig. 15 に示す。灰は中心周波数が大きく歪みフェージン グを生ずるが，黒に歪みはない. Fig. 14 においてスループット 低下部の受信電力が増加することや，矩形導波管の無線伝搬特 性（Fig. 6, Fig. 7）の結果を勘案すると，スループット低下部 は無線中心周波数 $2.412[\mathrm{GHz}]$ で共振（共鳴）している可能性 が考えられるが，具体的な原因については今後の実験あるいは 解析により解明したい. 


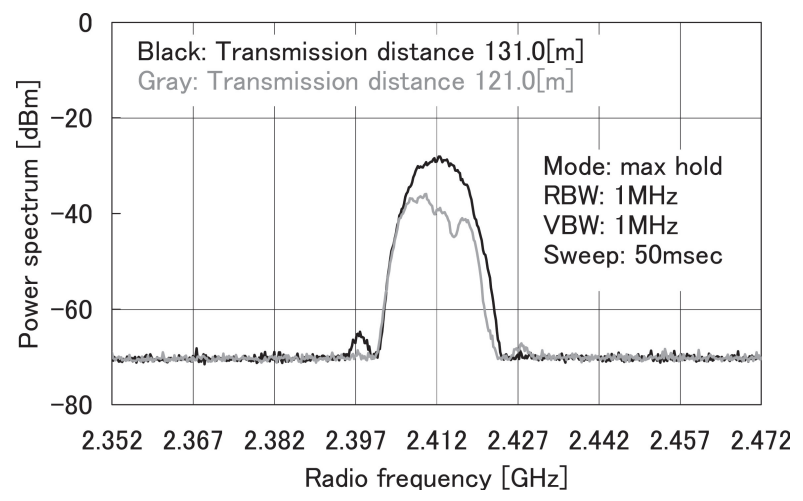

Fig. 15 Power spectrum of the received signal

\section{6. ベンドにおける通信不具合解消策}

マルチパスによる通信不具合を解消する方法として, 電波吸 収体などを用いた伝搬環境の改善, 伝搬劣化に強い変調方式の 採用, ダイバーシチアンテナやアダプティブアレーアンテナな ど伝搬劣化を軽減する工夫などが考えられる。

このうち，前章までの検討で，電波吸収体を用いると鉄管中 心軸方向の反射は改善できるが, 鉄管直径方向の反射は改善で きないことが分かっている.

一方，マルチキャリア変調方式の 1 種である OFDM（Orthogonal frequency division multiplexing) が開発されてい る. OFDM は，(1) 電力スペクトルが周波数帯域を有効利用 するための理想的な形状をして㧍り, 他の変調方式に比べてシ ンボル長を長く確保できシンボル間干渉の割合を少なくできる, （2）ガードインターバルを設けることにより，ママルチパスの遅 延広がりがガードインターバル未満であればシンボル間干渉を 除去できる, などの特徴がある [19].

さらに，ダイバーシチ技術の一つとして MIMO（Multiple input multiple output）が開発されている. MIMO は複数の アンテナから異なるデータを送信し, 複数のアンテナで受信す ることにより，デー夕伝送の高速化を図る技術である [19].

現在, 我が国では, OFDM 変調方式と MIMO ダイバーシチ 技術を組み合わせた IEEE $802.11 \mathrm{n}$ という通信規格（以下，11n 規格と呼ぶ）が認可され，無線 LAN ルータなどで広く使われ ている [19]. そこで，本研究では，ベンドを含む水圧鉄管（見 通し外通信）の通信不具合解消策として, $11 \mathrm{n}$ 規格の無線 LAN ルータを検討する。

\section{7. 屋内実験装置による無線伝搬特性測定（2）}

\section{1 屋内実験装置 (2)}

見通し外通信環境における無線伝搬特性を測定するため, 屋 内実験装置（1）のアルミ矩形筐体を 2 段重政にし，接続端を円 弧状の電波反射板（アルミ板）で連結した U 字型筐体を製作し た，製作した実験装置の寸法形状を Fig. 16 に示す，図の下段 には位置可変の受信アンテナ, 上段には位置固定の送信アンテ ナが配置され, 送受信距離は $6.758 \sim 3.940[\mathrm{~m}]$ の間で変化させ ることができる, 送受信方向端面は, アルミ板で閉塞, 電波吸 収体で閉塞, 両端開放の 3 ケースを選択できる, 実験では, 図

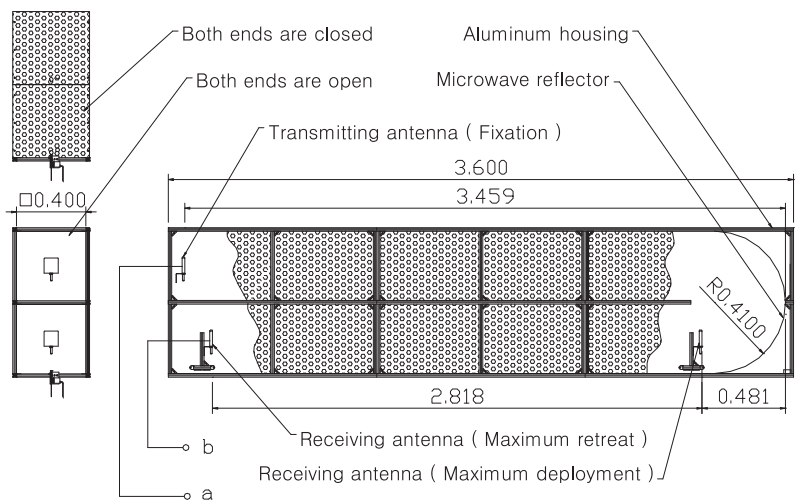

Fig. 16 Indoor experimental apparatus for producing a multipath environment of over-the-horizon area

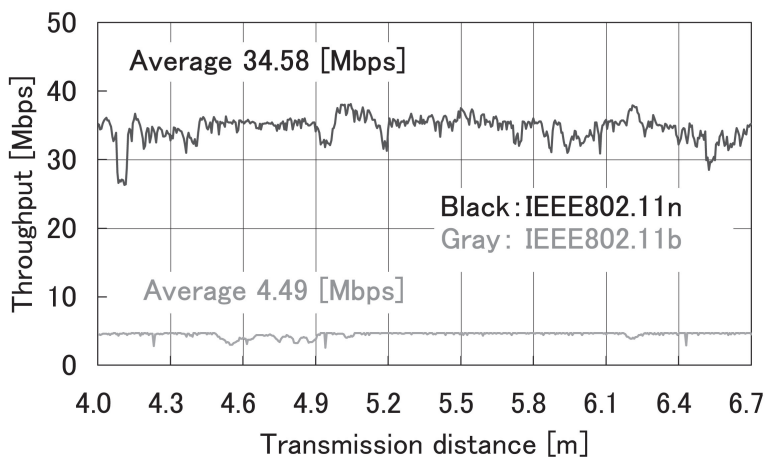

Fig. 17 Throughput of two types of wireless LAN (IEEE802.11n / 11b) in over-the-horizon environment

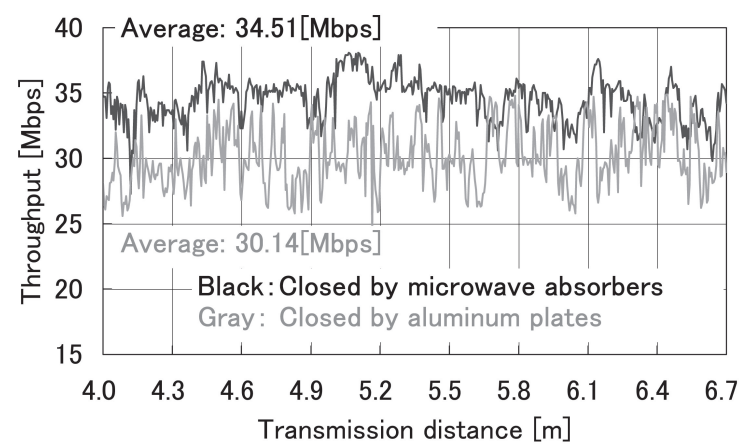

Fig. 18 Throughput comparison of the case which are closed by microwave absorbers and the case which are closed by aluminum plates (IEEE802.11n)

の端子 $\mathrm{a}$ と bに Fig. 2 の Iperf の端子 $\mathrm{g}$ と h を接続して測定を

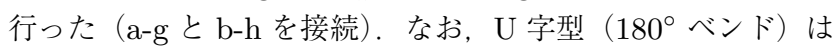
通常の水圧鉄管には存在しない, 無線伝搬にとって最も厳しい 見通し外通信環境である。

\section{2 測定結果}

Fig. 17 は屋内実験装置（2）の端面を開放した場合の，11n 規格および $11 \mathrm{~b}$ 規格の無線 LAN ルー夕の送受信距離に対す るスループットの変化である。黒は $11 \mathrm{n}$ 規格, 灰は $11 \mathrm{~b}$ 規格, Average はそれぞれの全送受信距離の単純平均を表す。図より, 見通し外通信環境における $11 \mathrm{n}$ 規格のスループットの単純平均 は $11 \mathrm{~b}$ 規格の 7.7 倍で, 全送受信距離に対する值もほぼ安定し 
ている。すなわち, 屋内実験装置（2）に関する限り，11n 規格 の無線 LAN ルータはデータ伝送の安定性を損なうことなく高 速化を実現しており，ベンドを含む水圧鉄管の通信不具合解消 策として期待できる。

Fig. 18 は, 屋内実験装置（2）の端面をアルミ板または電波 吸収体で閉塞した場合の, $11 \mathrm{n}$ 規格の無線 LAN ルータの送受 信距離に対するスループットの変化である. 黒は電波吸収体で 端面閉塞, 灰はアルミ板で端面閉塞, Average はそれぞれの全 送受信距離の単純平均を表す。眓において, 全送受信距離にお いて黒のスループットは灰を上回っており, 単純平均で比較す ると, 黒 34.51 [Mbps] は灰 30.13 [Mbps] よりスループットが $14.5 \%$ 向上している。すすなわち，見通し外通信環境においても， 送受信方向（U 字型筐体中心軸方向）の端面に電波吸収体を設 置すると，スループット向上に効果があることが分かる.

\section{8. 実機水圧鉄管による無線通信実験（2）}

\section{1 使用水圧鉄管}

使用水圧鉄管は, 2012 年度の当社水力発電所の停電作業計画 および停電作業期間, 水圧鉄管の寸法形状を考慮して, $U$ 発電 所水圧鉄管を選定した，U 発電所は, 当社が管理するダム水路 式発電所で, 出力 $25,000[\mathrm{~kW}]$, 水圧鉄管条数 1 条, 水圧鉄管 内径 $\Phi 2.75[\mathrm{~m}] \sim \Phi 1.80[\mathrm{~m}]$, 水圧鉄管延長 $322[\mathrm{~m}]$ である.

U 発電所水圧鉄管の縦断面図を Fig. 19 に示す。図におい

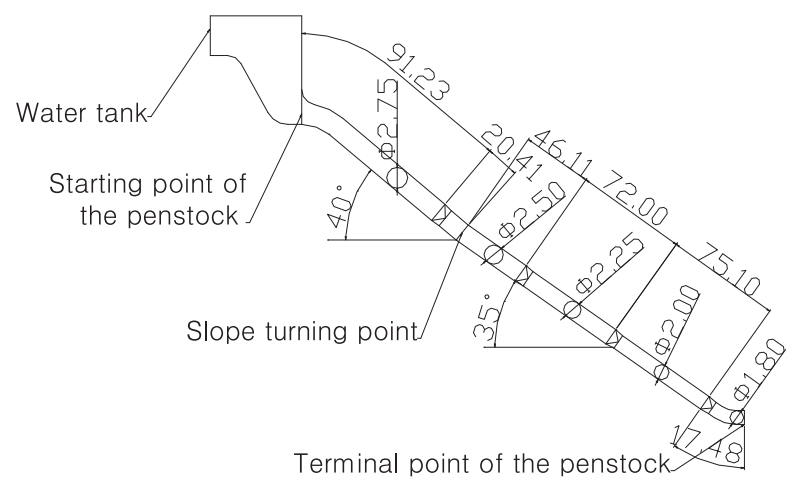

Fig. 19 Longitudinal section of the penstock of " $U$ " hydroelectric power station

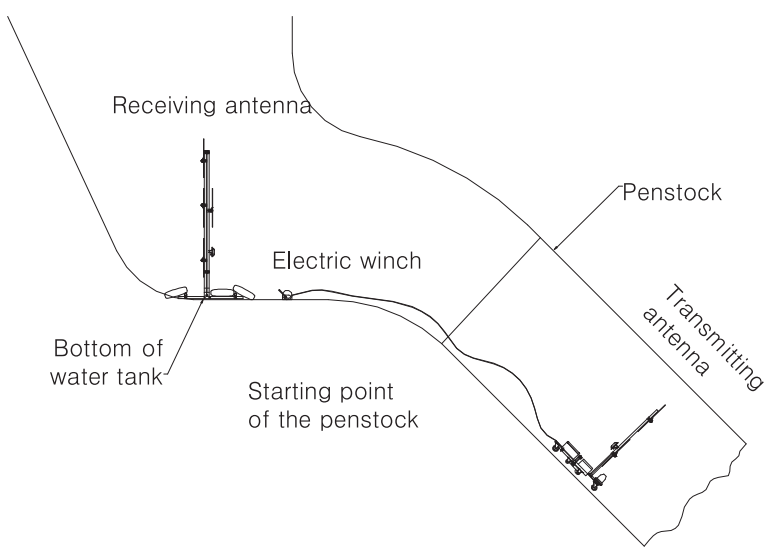

Fig. 20 Device configuration and arrangement of the wirelesscommunications experiment (2)
て, 水圧鉄管は水槽直後に勾配 $40^{\circ}$ となり。水圧鉄管始点から $111.64[\mathrm{~m}]$ の位置で勾配 $35^{\circ}$ になる。 また, 無線通信実験中（停 電作業期間中） は水圧鉄管終点の入口弁が閉じられ，水圧鉄管 は終点が鉄製屝で閉塞された状態になる。

\section{2 実験方法}

実験機材の構成と配置を Fig. 20 に示す，実験機材は，水槽 上部から吊り下げて搬入し, 受信アンテナと電動ウィンチを水 槽底部の基地局に固定する. 次に, 送信アンテナを電動ウィン チで水圧鉄管終点まで移動させながら, スループットと受信信 号のスペクトル分布を測定する. この場合, 水圧鉄管は, 送受信 アンテナ間にベンドを含む見通し外通信区間になる．無線 LAN ルータは, Table 1 と Table 2 の 2 種類を用いる.

\section{3 実験結果}

Fig. 21 は送受信距離に対するスループットの変化である. 黒 は $11 \mathrm{n}$ 規格の無線 LAN ルータ (Table 2), 灰は $11 \mathrm{~b}$ 規格の無 線 LAN ルータ（Table 1) を示す。また, Average はそれぞれ の全送受信距離の単純平均を表す（灰は $190[\mathrm{~m}]$ までの区間). 図より, 灰は送受信距離 $190[\mathrm{~m}]$ 以降にデー夕送受信が行えなく なるが, 黒線は送受信距離 $300[\mathrm{~m}]$ のほぼ全域に亘り安定的に データ送受信を行っている. また, 黒のスループットの単純平均 25.77 [Mbps] は灰の 10 倍に達し, 目標スループット 3 [Mbps] を十分に上回るデータ伝送速度を達成している.

Fig. 22 は 11n 規格の無線 LAN ルータの電力スペクトルで ある. 黒は送受信距離 $250[\mathrm{~m}]$, 灰は送受信距離 $3[\mathrm{~m}]$ を示す. 図より, 送受信距離が伸びても電力スペクトルに歪や減衰が生 じておらず，通信状態が良好なことが分かる。

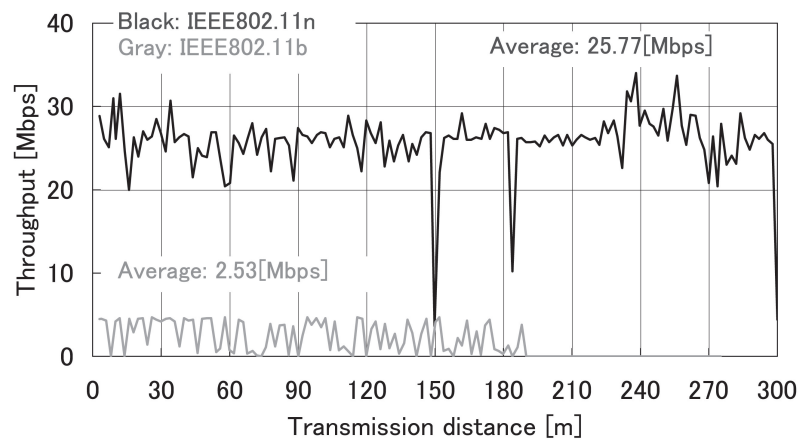

Fig. 21 Change of throughput to transmission distance

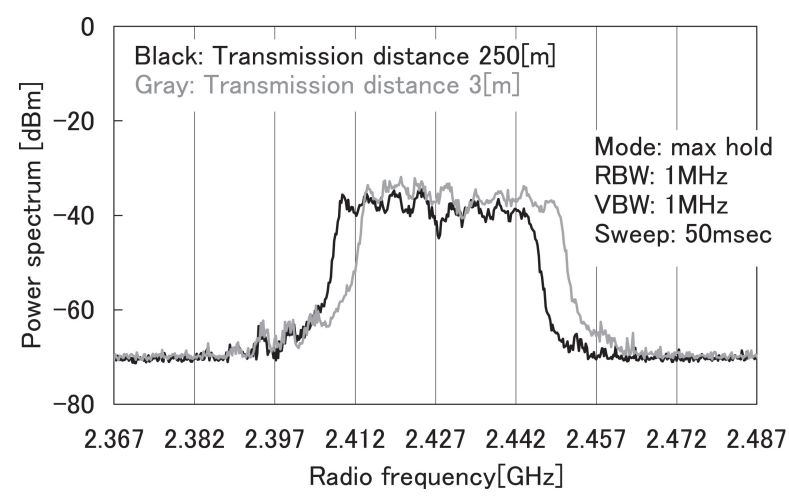

Fig. 22 Power spectrum of the received signal 
Fig. 21，22 の結果より, MIMO ダイバーシチ機能を持つ OFDM 変調方式の無線 LAN ルータを用いると, ベンドを含む水 圧鉄管（見通し外通信）の通信不具合がほぼ解消され，U 発電所 水圧鉄管内部で高速デー夕伝送を実現できることが確認された。

なお, OFDM 変調方式はマルチパスの遅延広がりがガード インターバルを超えると通信不具合を生じるが, 本研究で考案 した電波吸収体付きアンテナを用いると遅延広がりが大きい鉄 管中心軸方向の反射が吸収される，また，MIMO ダイバーシチ 機能は, 複数のアンテナからデータを送信するためデー夕伝送 の高速化が見込まれる，そのため，電波吸収体付きアンテナと MIMO ダイバーシチ機能を持つ OFDM 変調方式の無線 LAN ルータを組み合わせることにより, 良好な無線伝搬環境を維持 できると思われる。

\section{9. を と め}

以上の検討により，水圧鉄管直線部（見通し内通信）につい ては本研究で考案した電波吸収体付きアンテナと DSSS 変調方 式の無線 LAN ルー夕を組み合わせると, ベンドを含む水圧鉄 管（見通し外通信）については本研究で考案した電波吸収体付 きアンテナと MIMO ダイバーシチ機能を持つ OFDM 変調方 式の無線 LAN ルー夕を組み合わせると, まれに発生する局所 的なスループットの低下を除いて, 通信不具合がほぼ解消でき る見通しがついた。

今回の無線通信実験は $2.4[\mathrm{GHz}]$ 帯を対象にしたが, 文献 [9] [10] [12] では，無線周波数が高くなるほど無線が通りやす いことが報告されている. IEEE $802.11 \mathrm{n}$ 規格は $2.4[\mathrm{GHz}]$ 帯と $5[\mathrm{GHz}]$ 帯の両方が使用可能なため, 今後は $5[\mathrm{GHz}]$ 帯の無線伝 搬特性を測定してマルチパス環境に強い周波数带を選定し, 水 圧鉄管直線部（見通し内通信）に扔ける $11 \mathrm{n}$ 規格の有効性を確 認した上で，水圧鉄管内部の無線通信システムとして実用化を 目指したい.

なお， $\mathrm{K}$ 発電所および $\mathrm{U}$ 発電所の実機水圧鉄管の無線通信実 験では, 電波の共振（共鳴）を裏付けるデー夕不足や, $11 \mathrm{n}$ 規 格の無線 LAN ルータで見通し内通信実験を行っていないなど, 一部不十分な内容があるが, 電力需給逼迫のため停電期間を短 縮せざるを得なくなり無線通信実験に十分な時間を割けなかっ たという弊社の現状をご理解戴き, ご容赦を賜りたい.

謝 辞 本研究の実機水圧鉄管による無線通信実験デー夕は, $\mathrm{K}$ 発電所㧍よび $U$ 発電所の停電作業期間を利用して取得したも のである，スケジュール調整・現地での安全管理をしていただ いた, 北海道電力（株）本店水力部, 旭川水力センター芦別土 木課, 日高水力センター, 総合研究所火力・土木技術グループ 各位に感謝いたします。また，無線通信実験の作業補助をして いただいた北電総合設計（株）およびジオテック（株）の関係 者に,この場を借りて感謝いたします。

\section{参 考 文 献}

[1] 山崎尊志, 浅野雅則, 山下卓也： “高速画像処理を用いた下水道管渠 内 TV カメラ調査システムの開発”, 下水道研究発表会講演集, 第 44 回, pp.535-537, 2007.

[ 2 ] 佐藤武志, 西田陽嗣, 森沢光一：“遠隔操作システムによる管内部点 検の効率化”, 電力土木, vol.304, pp.14-17, 2003.

[ 3 ] 東電工業株式会社ホームページ, ロボット点検システム, http://www. todenkogyo.co.jp/service/sb01.html

[4] 川口圭史, 吉田乙雄, 車谷治通, 菊田隆：“鉄管内走行ロボットの開 発”, 日本ロボット学会誌, vol.14, no.1, pp.137-143, 1996.

[5] 多田達美, 鈴木慎一, 川崎宏 : “暗渠洗浄ロボットの事業化高耐久性 暗渠排水管検査・洗浄装置の開発 (平成 20 年度)”, 北海道立工業試 験場成果発表会発表要旨, p.39, 2009.

[ 6 ] 川崎宏 : 内視機能等を備えた方向制御可能な小径管内の洗浄装置, 日 本国特許庁，特開 2005-58904, 2005.

[ 7 ] 吉澤良, 福澤修一朗, 高橋行彦: “水圧鉄管内面点検装置の開発”, 電 力土木, vol.348, pp.14-17, 2010.

[8] 吉野智彦, 片山誠, 村上岩範, 安藤嘉則, 長屋幸助: “無線式磁気吸 着配管内検査ロボットの開発”, 日本 AEM 学会誌, vol.17, no.3, pp.508-514, 2009.

[ 9 ] 佐々木伸： “トンネル内のマイクロ波伝搬特性と零進法”, 鉄道技術研 究報告, vol.1343, pp.1-46, 1987 .

[10] 佐々木範雄, 御供輝充, 千葉二郎：“導水路トンネルのマイクロ波 帯における減衰定数の実験式”, 電気学会論文誌 C, vol.121, no.2, pp.438-444, 2001.

[11] 大津良司： “トンネル内無人飛行船画像伝送 地下空間・狭盆空間に おける無人移動体通信技術”, 建設の施工企画, vol.747, pp.50-56, 2012.

[12] 平井淳一： “トンネル内画像無線伝送システムの開発 - トンネル内で 無線により画像を伝送”, 建設機械, vol.33, no.10, pp.44-47, 1997.

[13] 唐沢好男 : デジタル移動通信の電波伝搬基礎. コロナ社, 2006.

[14] 下条則之, 唐沢好男： “等価伝送路モデルを用いた符号間干渉誤り発 生空間分布の簡易な計算法一屋内伝搬環境を例として—”, 電子情報 通信学会技術研究報告, AP2000 195-200, pp.33-40, 2001.

[15] 上原一浩, 関智弘, 鹿子嶋憲一: “幾何学的手法による任意指向性ア ンテナに対する屋内伝搬特性解析”, 電子情報通信学会論文誌 B-2, vol.78, no.9, pp.593-601, 1995.

[16] 原弘和, 本島邦行, 松原雅昭: “変形導波管内における電磁波伝搬解 析”, 電子情報通信学会論文誌 (C), vol.J93-C, no.9, pp.331-334, 2010.

[17] 福澤修一朗：“水力発電所水圧鉄管内部の無線通信実験について”, 日 本ロボット学会第 30 回記念学術講演会, AC4G1-4, 2012.

[18] 米国 NCSA ホームページ, http://www.ncsa.illinois.edu/News/ datalink/0410/nlanr.html

[19] 伊丹誠：分かりやすい OFDM 技術. pp.1-181, オーム社, 2005.

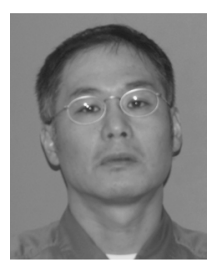

福澤修一朗（Shuichiro Fukuzawa）

1986 年早稲田大学理工学部機械工学科卒業. 1988 年東京大学大学院工学系研究科航空学専攻修士課程 修了. 1991 年東京大学大学院工学系研究科航空学 専攻博士課程単位取得退学. 同年文部省宇宙科学研 究所衛星応用工学研究系技術補佐員. 1994 年より 北海道電力株式会社総合研究所研究員, 現在に至る. 1997 年に博士 (工学) 取得. 電力設備の保守点検にかかわる技術開発. 装置開発に従事. 日本航空宇宙学会会員. (日本ロボット学会正会員) 